\title{
The Impact of Electronic Banking Services on Customer Satisfaction in the Sudanese Banking Sector
}

\author{
Adam Ahmed Musa Hamid ${ }^{1}$, Nabil Mohamed Abdo Alabsy ${ }^{2}$, Mohanad Abbas Mukhtar ${ }^{2}$ \\ ${ }^{1}$ Elemam Almahdi University, Sudan \& Bisha University, College of Business, Saudi Arabia \\ ${ }^{2}$ Bisha University, College of Business, Saudi Arabia \\ Correspondence: Nabil Mohamed Abdo Alabsy, Bisha University, College of Business, Saudi Arabia. \\ E-mail: nabil8877@yahoo.com
}

$\begin{array}{ll}\text { Received: January 10, } 2018 & \text { Accepted: May 4, } 2018 \quad \text { Online Published: May 18, } 2018 \\ \text { doi:10.5539/ibr.v11n6p102 } & \text { URL: https://doi.org/10.5539/ibr.v11n6p102 }\end{array}$

\begin{abstract}
This research paper aims to study the impact of electronic banking services on customer satisfaction at Sudanese banks. Questionnaires were designed by the researchers. Data and information have been collected and analyzed from the internet users in the Sudanese banks clients. The study found that there are statistical significant differences of electronic services provided by the Sudanese banks on customer satisfaction. The study attempted to explain the various means of electronic banking services which might lead to the customer satisfaction.
\end{abstract}

This paper showed that the banking services over the internet has a positive impact on customer satisfaction. This study recommended that the bank management should focus on spreading the knowledge of the electronic banking services to the customers. This study emphasized the importance of the electronic banking services and recommended that the bank management should spread the technological awareness among current and prospective customers, and develop suitable infrastructure for electronic banking services in the Sudanese banking sector.

Keywords: electronic banking services, customer satisfaction, service quality, Sudanese banks, automatic teller machine

\section{Introduction}

The importance of service sector has been increased in the recent years with the increase of the customers in the banking sector and its role in the development of the economic sector in Sudan.

In marketing term, customer satisfaction is described as a measure on how services or products supplied by the organizations meet customers' expectation. The awareness of customers in service industries about quality has been increased. The excellent service quality increases the productivity, market share, return on investment, and customer satisfaction. Nowadays the quality has gained more importance through the customer satisfaction.

Since the sixteenth of previous century the firms want to get superior values for their goods and services. Every organization has to serve its customers according to their wants efficiently and effectively. In recent years the banks are racing for providing the highest technology infrastructure, these lead to wide use of electronic banking services through wide spread of internet websites for fulfilling the requirements of the customers. Despite the differences of the services offered in respect of prices and types of offering electronic services, most of the banks use electronic banking services for buying, selling and exchanging services through the electronic websites which known as an electronic commerce. For this reason, the researchers adopted the idea of this research topic about electronic banking services and its impact on customer satisfaction at Sudanese banks. The study started in January, 2017 and completed in December, 2017.

\section{Objectives of the Study}

1. To study the concept of quality in electronic banking services.

2. To evaluate the effect of electronic banking services on customer satisfaction from customers point of view.

3. To know the extent of differences between customer's expectation about quality of electronic banking services and bank management's perception. 


\section{Hypothesis of the Study}

1. There is a significant positive relationship between the internet websites services and customer satisfaction about services offered by the Sudanese banks.

2. There is a significant positive relationship between the Automatic Teller Machine services and customer satisfaction about services offered by the Sudanese banks.

3. There is a significant positive relationship between the phone banking services and customer satisfaction about services offered by the Sudanese banks.

\section{Literature Review}

Alhaliq, H. A., \& AlMuhirat, A. A. (2016) examined the extent of customer satisfaction with electronic banking services in the Saudi banking sector and found that Saudi banks have succeeded in attaining significant customer satisfaction due to the better quality of the services offered and better performance and facilitating electronic transactions.

Alhori, F. (2006) clarified the importance of using of communication technology for enhancing competitive advantages in the Jordanian banking sector. The study aimed to demonstrate the importance of the adoption of competitive strategy so that the company can compete with other companies.

Al-Abed (2003) stated that electronic banking is an umbrella term for the process by which a customer may perform banking transactions electronically without visiting the bank personally. He describes electronic banking as a variety of the following platforms: Internet banking, telephone banking, TV-based banking, mobile phone banking.

Alawamelh, M. et al. (2016) studied the impact of online banking services quality dimensions on customer satisfaction at Jordanian banks. The service quality dimensions are reliability, guarantee, empathy, response and physical evidence. The result of the study proved that the customers of the bank are satisfied with the services offered. The guarantee was the most important dimension for the customers.

Ling, G. et al. (2015) emphasized the importance of application of Internet banking as a viable tool to enhance and create customer satisfaction. According to this study the main problem the large number of customers are not willing to use the Internet banking services offered. In this study the authors decided five factors which can influence customer satisfaction toward Internet banking include convenience and speed, security and privacy, web design and content, and service quality.

Navaratnaseelan, J and Elangkumaran, P. (2014) stated that there is a positive relationship between service quality and customer satisfaction through the SERVQUAL model in the commercial bank of Ceylon PLC Trincomalee district. The researchers examined the quality dimensions such as tangibility, reliability, assurance, responsiveness and empathy and found that there is a strong positive relationship between service quality and customer satisfaction.

\section{Conceptual Framework}

\subsection{Electronic Banking Services}

Internet banking is a banking channel that allows consumers to do many transaction, either financial or non-financial through a bank's websites. The technological revolution produced modern technical instruments which have been used to facilitate and improve banking services. The electronic services represent the forms of self services, so that the customer can do what he needs himself. In this regard the electronic services should be designed on the basis of the needs, wants, expectations, and experiences of the customers according to the following standards, firstly the electronic services should have the easiness to use so that the customer can perform the tasks easily, secondly the speed of electronic services should be high, and finally the electronic services should have the credibility, and there should be compatibility between these services and other technical services.

The concept of electronic banking has been defined in many ways. Daniel (1999) defines electronic banking as the delivery of banks' information and services by banks to customers via different delivery platforms that can be used with different terminal devices such as personal computers and mobile phone with browser or desktop software, telephone or digital television.

\subsection{Quality of Electronic Services}

The concept of quality services and electronic services recently emerged in service industries. Parasuraman et al. (1985) provided a list of determinants of service quality in their focus group studies with service providers and 
customers they are: access, communication, competence, courtesy, credibility, reliability, responsiveness, security, understanding and tangibility.

\subsection{Customer Satisfaction}

Customer satisfaction depends on the expectations and perceptions about the offered services. The satisfaction concept depends on several psychological and physical variables. The satisfaction of customer with electronic services based on the benefits of the customer. The satisfaction with electronic service offered by the banks translated into behavior and practice that create a positive attitude toward the bank services.

\section{Data Collection and Analysis}

200 questionnaires were administered and distributed by the researchers to internet users customers. Regarding the Sudanese banks were Bank of Khartoum, Fisal Islamic Bank, Omdarman National Bank and Central Bank of Sudan. The following tables show the study sample from all dimensions of the study.

Table 1. Demographic characteristics for study sample

\begin{tabular}{llll}
\hline Items & Category & ]Frequency & Percentage \\
\hline Sex & Male & 154 & 77 \\
& Female & 46 & 23 \\
Age & Less than 30 years & 11 & 5.5 \\
& 30 to 40 years & 164 & 82 \\
& Above 40 years & 25 & 12.5 \\
Occupation & Employee & 101 & 50.5 \\
& Merchant & 95 & 47.5 \\
& Worker & 2 & 1 \\
Type of account & Others & 2 & 1 \\
& Current & 146 & 73 \\
& Saving & 48 & 24 \\
Date of opening an account & Other & 6 & 3 \\
& Since 1 year & 46 & 23 \\
& Since 2 years & 43 & 21.5 \\
& More than 2 years & 111 & 55.5 \\
\hline
\end{tabular}

The above table indicates that the percentage of male is $77 \%$ while the percentage of female is $23 \%$ of the study sample, also the ages of the respondents who were in the range between 30 to 40 were the majority $82 \%$. Regarding the occupation the majority of the respondents were employees 50.5. In the account type the majority of respondents have a current account, however most of respondents opened their accounts more than two years ago $55.5 \%$. 
Table 2. Electronic banking service and automatic teller machine ( ATMs)

\begin{tabular}{|c|c|c|c|c|c|c|c|c|c|c|}
\hline \multirow[t]{2}{*}{ Items } & \multicolumn{2}{|c|}{$\begin{array}{l}\text { Strongly } \\
\text { agree }\end{array}$} & \multicolumn{2}{|c|}{ Agree } & \multicolumn{3}{|c|}{$\begin{array}{l}\text { Neither } \\
\text { agree } \\
\text { nor } \\
\text { disagree }\end{array}$} & Disagree & \multicolumn{2}{|c|}{$\begin{array}{l}\text { Strongly } \\
\text { disagree }\end{array}$} \\
\hline & $\mathrm{Fr}$ & $\%$ & Fr. & $\%$ & Fr. & $\%$ & Fr. & $\%$ & Fr. & $\%$ \\
\hline $\begin{array}{l}\text { The bank updates } \\
\text { the electronic banking } \\
\text { services. }\end{array}$ & 87 & 43.5 & 101 & 50.5 & 8 & 4 & 3 & 1.5 & 1 & 0.5 \\
\hline $\begin{array}{l}\text { ATMs improve the } \\
\text { reputation of the bank. }\end{array}$ & 45 & 22.5 & 124 & 62 & 8 & 4 & 15 & 7.5 & 8 & 4 \\
\hline $\begin{array}{l}\text { Geographical spread of } \\
\text { the ATMs increases the } \\
\text { number of customers. }\end{array}$ & 25 & 12.5 & 139 & 69.5 & 22 & 11 & 13 & 6.5 & 1 & 0.5 \\
\hline $\begin{array}{l}\text { ATMs increase the trust } \\
\text { of customers. }\end{array}$ & 58 & 29 & 94 & 47 & 11 & 5.5 & 29 & 14.5 & 8 & 4 \\
\hline $\begin{array}{l}24 \text { hours business hours } \\
\text { for ATMs increase the } \\
\text { loyalty of customers. }\end{array}$ & 77 & 38.5 & 63 & 31.5 & 12 & 6 & 25 & 12.5 & 23 & 1.5 \\
\hline $\begin{array}{l}\text { ATMs improve the } \\
\text { banking services of the } \\
\text { customers. }\end{array}$ & 57 & 28.5 & 128 & 64 & 7 & 3.5 & 3 & 1.5 & 5 & 2.5 \\
\hline $\begin{array}{l}\text { ATMs offer high quality } \\
\text { services. }\end{array}$ & 59 & 29.5 & 101 & 50.5 & 28 & 14 & 11 & 5.5 & 1 & 0.5 \\
\hline $\begin{array}{l}\text { Geographical distribution } \\
\text { of ATMs leads to the } \\
\text { decrease of the time of } \\
\text { waiting for the customer. } \\
\text { The customers become } \\
\text { less dependent on the } \\
\text { official working hours in } \\
\text { the bank by using ATMs. }\end{array}$ & 105 & 22.5 & 131 & 65.5 & 14 & 11 & 13 & 6.5 & 2 & 0.5 \\
\hline $\begin{array}{l}\text { The money transfer } \\
\text { becomes more easier } \\
\text { through using ATMs. }\end{array}$ & 57 & 28.5 & 118 & 59 & 17 & 8.5 & 6 & 3 & 2 & 1 \\
\hline
\end{tabular}

The table shows that most of the respondents agreed that the bank has updated the electronic banking services $94 \%$, while $2 \%$ of the respondents disagreed with that statement, while $4 \%$ of the respondents did not decide their opinions. Regarding the statement that ATMs have increased the reputation of the bank most of the respondents $84.5 \%$ agreed with this statement, while $11.5 \%$ disagreed and $4 \%$ did not decide. $82.5 \%$ of the respondents agreed that the geographical spread for the ATMs increased the number of customers, while 7\% disagreed and $11 \%$ did not decide. $76 \%$ from the respondents agreed with the statement ATMs increased the trust of customers, while $18.5 \%$ disagreed and 5.5 did not decide. Most of the respondents agreed that 24 hours business hours for ATMs increased the loyalty of customers with $70 \%$, while $24 \%$ disagreed and $6 \%$ did not decide. Regarding the statement that ATMs improve the banking services of the customers with $92.5 \%$ agreed with this statement, while $4 \%$ disagreed and 3.5\% did not decide. For the statement ATMs offered high quality services, $80 \%$ of respondents agreed with this statement, while $6 \%$ disagreed and $14 \%$ did not decide. In the statement of geographical distribution for ATMs leads to the decrease of the time of waiting for the customers $80 \%$ agreed, while 5\% disagreed and 7\% were undecided. For the statement customers become less dependence on the official working hours in the bank by using ATMs $82 \%$ of the respondents agreed and $7 \%$ disagreed while $11 \%$ undecided. In the statement that the money transfer become more easier through using ATMs $87.5 \%$ agreed with this opinion and $4 \%$ disagreed, while $8.5 \%$ did not decide. 
Table 3. The electronic banking services and the internet

\begin{tabular}{|c|c|c|c|c|c|c|c|c|c|c|}
\hline \multirow[t]{3}{*}{ Items } & \multirow{2}{*}{\multicolumn{2}{|c|}{$\begin{array}{l}\text { Strongly } \\
\text { agree }\end{array}$}} & \multirow{2}{*}{\multicolumn{2}{|c|}{ Agree }} & \multirow{2}{*}{\multicolumn{2}{|c|}{$\begin{array}{l}\text { Neither } \\
\text { agree nor } \\
\text { Nor disagree }\end{array}$}} & \multirow{2}{*}{\multicolumn{2}{|c|}{ Disagree }} & \multirow{2}{*}{\multicolumn{2}{|c|}{$\begin{array}{l}\text { Strongly } \\
\text { disagree }\end{array}$}} \\
\hline & & & & & & & & & & \\
\hline & Fr. & $\%$ & Fr. & $\%$ & Fr. & $\%$ & Fr. & $\%$ & Fr. & $\%$ \\
\hline $\begin{array}{l}\text { Readiness of the bank to serve the customer } \\
\text { becomes higher through using the internet. }\end{array}$ & 116 & 58 & 31 & 15.5 & 25 & 12.5 & 23 & 11.5 & 5 & 2.5 \\
\hline $\begin{array}{l}\text { The customer becomes more satisfied through the } \\
\text { transaction with internet banking. }\end{array}$ & 70 & 35 & 72 & 36 & 3 & 1.5 & 40 & & 15 & 7.5 \\
\hline $\begin{array}{l}\text { Privacy, secrecy and safety have increased the trust } \\
\text { of the customer's transaction with internet banking. }\end{array}$ & 55 & 27.5 & 95 & 47.5 & 18 & 9 & 29 & 14.5 & 3 & 1.5 \\
\hline $\begin{array}{l}\text { Payment of the bills (telephone, water, } \\
\text { electricity...etc.)through the internet banking has } \\
\text { increased customer satisfaction. }\end{array}$ & 69 & 34.5 & 117 & 58.5 & 3 & 1.5 & 5 & 2.5 & 6 & 3 \\
\hline $\begin{array}{l}\text { Providing the electronic banking services in time } \\
\text { and in suitable place has increased the customer } \\
\text { satisfaction. }\end{array}$ & 43 & 21.5 & 113 & 56.5 & 6 & 3 & 20 & 10 & 18 & 9 \\
\hline $\begin{array}{l}\text { Providing electronic channel between the bank and } \\
\text { the customer has increased the customer } \\
\text { satisfaction. }\end{array}$ & 38 & 19 & 106 & 53 & 16 & 8 & 31 & 15.5 & 9 & 4.5 \\
\hline $\begin{array}{l}\text { Electronic reply to the customers' inquiries has } \\
\text { increased the customers' satisfaction. }\end{array}$ & 28 & 14 & 130 & 65 & 26 & 13 & 5 & 2.5 & 11 & 5.5 \\
\hline $\begin{array}{l}\text { Display of bank account and balance electronically } \\
\text { has increased the customer satisfaction. }\end{array}$ & 79 & 39.5 & 76 & 38 & 30 & 15 & 10 & 5 & 5 & 2.5 \\
\hline $\begin{array}{l}\text { Electronic deposit and money transfer have } \\
\text { increased customer satisfaction. }\end{array}$ & 77 & 38.5 & 69 & 34.5 & 28 & 14 & 24 & 14 & 2 & 1 \\
\hline $\begin{array}{l}\text { Providing electronic banking services has increased } \\
\text { the stability of electronic services. }\end{array}$ & 49 & 24.5 & 123 & 61.5 & 6 & 3 & 16 & 8 & 6 & 3 \\
\hline $\begin{array}{l}\text { Continuous communication with bank account } \\
\text { holder has increased customer's loyalty. }\end{array}$ & 86 & 43 & 103 & 51.5 & 3 & 1.5 & 6 & 3 & 4 & 1 \\
\hline
\end{tabular}

holder has increased customer's loyalty.

The first statement shows that $73.5 \%$ of the respondents have agreed that readiness of the bank to serve the customer becomes higher through using the internet, while $14 \%$ disagreed and $12.5 \%$ did not decide. Regarding the statement the customer becomes more satisfied through the transaction with internet banking it is found that $71 \%$ of the respondents agreed with the above statement, while $27.5 \%$ disagreed and $1.5 \%$ did not decide. According to the statement privacy, secrecy and safety increased the trust of the customer's transaction with internet banking it is found $75 \%$ agreed with this statement, while $16 \%$ disagreed and $9 \%$ were undecided. In the statement payment of the bills (telephone, water, electricity...etc.) through the internet to the bank increased customer satisfaction, it is found that $83 \%$ agreed, while $5.5 \%$ disagreed and $1.5 \%$ did not decide. For the statement providing the electronic banking services in time and in suitable place increases the customer satisfaction $78 \%$ of the respondents agreed, while $19 \%$ disagreed and 3\% did not decide. About the statement of providing electronic channel between the bank and the customer increased the customer satisfaction, it is found that $72 \%$ agreed with the statement, while $20 \%$ disagreed, while $8 \%$ did not decide. In the statement of providing electronic channel between the bank and the customer increases the customer satisfaction, it is found $79 \%$ agreed with this statement, and $8 \%$ disagreed, while $13 \%$ did not decide. $77.5 \%$ agreed with the statement of electronic reply to the customers' inquiries increased the customers satisfaction, while $7.5 \%$ disagreed with this statement, while $15 \%$ were undecided. $77.5 \%$ agreed with the statement that display of bank account and balance electronically increases the customer satisfaction, while $7.5 \%$ disagreed, while $15 \%$ did not decide. $73 \%$ of the respondents agreed that electronic deposit and money transfer increases customer satisfaction, while $13 \%$ disagreed, where as $14 \%$ did not decide. Regarding the statement of providing electronic banking services increases the stability of electronic services, it is found $86 \%$ agreed with this statement, while $11 \%$ disagreed with this statement and $11 \%$ did not decide. Finally in the statement continuous communication with bank account holder has increased customer's loyalty, it is found that $94.5 \%$ agreed with this statement, while $4 \%$ were disagreed and $1.5 \%$ did not decide. 
Table 4. Electronic banking services and telephone banking

\begin{tabular}{|c|c|c|c|c|c|c|c|c|}
\hline \multirow[t]{2}{*}{ Items } & \multirow[b]{2}{*}{$\overline{\mathrm{Fr}}$} & \multirow[t]{2}{*}{$\begin{array}{l}\text { Strongly } \\
\text { agree }\end{array}$} & \multirow[t]{2}{*}{ Agree } & \multicolumn{2}{|c|}{$\begin{array}{l}\text { Neither agree } \\
\text { nor disagree }\end{array}$} & Disagree & \multicolumn{2}{|c|}{$\begin{array}{l}\text { Strongly } \\
\text { disagree }\end{array}$} \\
\hline & & & & Fr. \% & & $\%$ & & $\%$ \\
\hline $\begin{array}{l}\text { I feel secure when I receive the } \\
\text { messages from the bank after financial transaction. }\end{array}$ & 86 & 43 & 10351.5 & 10. & 9 & 4.5 & 1 & 0.5 \\
\hline $\begin{array}{l}\text { Sending exchange rate and interest rate through the } \\
\text { phone boost of customer trust. }\end{array}$ & 81 & 40.5 & 10251 & 52. & 5 & 2.5 & 7 & 3.5 \\
\hline $\begin{array}{l}\text { Sending marketing programs for the bank through } \\
\text { the phone increases the competitive advantage of the } \\
\text { bank. }\end{array}$ & 102 & 51 & $88 \quad 44$ & 21 & 5 & 2.5 & 3 & 1.5 \\
\hline $\begin{array}{l}\text { Using the bank phone as a tool for promotion of the } \\
\text { banking services increases the loyalty of the } \\
\text { customer. }\end{array}$ & 53 & 26.5 & 12261 & 42 & & 78.5 & 4 & 2 \\
\hline $\begin{array}{l}\text { Sending financial services through the phone to the } \\
\text { customer increases the customer trust on the bank. }\end{array}$ & 39 & 19.5 & 10753.5 & 2211 & & 2512.5 & 7 & 3.5 \\
\hline $\begin{array}{l}\text { Sending financial services through the phone to the } \\
\text { customer increases the customer satisfaction. }\end{array}$ & 37 & 18.5 & 12361.5 & 126 & & 211 & 6 & 3 \\
\hline
\end{tabular}

The first statement that I feel secure when I receive the messages from a bank after financial transaction, It is found that $94.5 \%$ agreed with the statement, $5 \%$ disagreed with this statement, while $0.5 \%$ did not decide. Regarding the statement of sending exchange rate and interest rate through the phone boosts of customer trust, it was found $91.5 \%$ of the respondents agreed with the statement, $9 \%$ were disagreed, and $2.5 \%$ did not decide. $95 \%$ of the respondents agreed with the statement of sending marketing programs for the bank through the phone increases the competitive advantage of the bank, $4 \%$ were disagreed, and $1 \%$ did not decide. In the statement of the bank using the phone as a tool for promotion of the banking services increases the loyalty of the customer, it was found $87.5 \%$ agreed with the statement, $10.5 \%$ disagreed with the statement, while $2 \%$ did not decide. $80 \%$ of the respondents agreed with the statement that sending financial services through the phone to the customer increases the customer trust on the bank, $14 \%$ were disagreed, while $6 \%$ did not decide. In the last statement sending financial services through the phone to the customer increases the customer satisfaction, it was found that $77.5 \% \mathrm{f}$ the respondents agreed, $16 \%$ disagreed, while 6.5 did not decide.

Table 5. Electronic banking service and automatic teller machines (ATMs)

\begin{tabular}{|c|c|c|}
\hline Items & $\begin{array}{l}\text { Standard } \\
\text { Deviation }\end{array}$ & Average \\
\hline The bank has updated the electronic banking services. & 1.008 & 4.11 \\
\hline ATMs improve the reputation of the bank. & 1.178 & 3.60 \\
\hline Geographical spread for the ATMs increases the number of customers. & 1.185 & 3.46 \\
\hline ATMs have increased the trust of customers. & 1.070 & 3.81 \\
\hline 24 hours business hours for ATMs have increased the loyalty of customers. & 1.111 & 3.47 \\
\hline ATMs improve the banking services of the customers. & 0.996 & 3.58 \\
\hline ATMs offer high quality services. & 1.141 & 3.09 \\
\hline $\begin{array}{l}\text { Geographical distribution for ATMs leads to the decrease of the time of } \\
\text { waiting for the customer. }\end{array}$ & 0.930 & 3.97 \\
\hline $\begin{array}{l}\text { The customers become less dependent on the official working hours in the } \\
\text { bank by using ATMs. }\end{array}$ & 0.900 & 3.98 \\
\hline The money transfer becomes more easier through using ATMs. & 1.062 & 3.80 \\
\hline
\end{tabular}

The above table shows that all the averages for the all statements were above 3 , which means that there is a 
positive relationship between electronic banking service and using automatic teller machines.

Table 6. The electronic banking services and the Internet

\begin{tabular}{|c|c|c|}
\hline Items & $\begin{array}{l}\text { Standard } \\
\text { Deviation }\end{array}$ & Average \\
\hline $\begin{array}{l}\text { Readiness of the bank to serve the customers become higher through using the } \\
\text { internet. }\end{array}$ & 1.194 & 3.8 \\
\hline The customer becomes more satisfied through the transaction with internet banking. & 1.122 & 3.8 \\
\hline $\begin{array}{l}\text { Privacy, secrecy and safety increased the trust of the customer's transaction with } \\
\text { internet banking. }\end{array}$ & 0.900 & 4.32 \\
\hline Payment of the bills (telephone, water, electricity...etc.) & .951 & 3.88 \\
\hline $\begin{array}{l}\text { Providing the electronic banking services in time and in suitable place increased the } \\
\text { customer satisfaction. }\end{array}$ & 1.023 & 3.79 \\
\hline $\begin{array}{l}\text { Providing electronic channel between the bank and the customer increased the } \\
\text { customer satisfaction. }\end{array}$ & 1.048 & 3.93 \\
\hline $\begin{array}{l}\text { Electronic reply to the customers' inquiries increased } \\
\text { the customers' satisfaction. }\end{array}$ & 0.938 & 3.97 \\
\hline $\begin{array}{l}\text { Display of bank account and balance electronically increased the customer } \\
\text { satisfaction. }\end{array}$ & 1.237 & 3.45 \\
\hline Electronic deposit and money transfer increased customer satisfaction. & 1.008 & 3.96 \\
\hline $\begin{array}{l}\text { Providing electronic banking services has increased the stability of electronic } \\
\text { services. }\end{array}$ & 1.097 & 4.14 \\
\hline $\begin{array}{l}\text { Continuous communication with bank account holder has increased customer's } \\
\text { loyalty. }\end{array}$ & 0.969 & 4.18 \\
\hline
\end{tabular}

Table 6 shows that all the averages for the all statements were above 3, which means that there is a positive relationship between the electronic banking services and using the Internet.

Table 7. The electronic banking services and telephone banking

\begin{tabular}{|c|c|c|}
\hline Items & $\begin{array}{l}\text { Standard } \\
\text { Deviation }\end{array}$ & Average \\
\hline I feel secure when I receive the messages from bank after financial transaction. & 0.778 & 4.48 \\
\hline $\begin{array}{l}\text { Sending exchange rate and interest rate through the phone boosts the customer } \\
\text { trust. }\end{array}$ & 1.005 & 4.22 \\
\hline $\begin{array}{l}\text { Sending marketing program for the bank through the phone has increased the } \\
\text { competitive advantage of the bank. }\end{array}$ & 1.097 & 4.14 \\
\hline $\begin{array}{l}\text { Using the bank phone as a tool for promotion of the banking services have } \\
\text { increased the loyalty of the customer. }\end{array}$ & 0.969 & 4.18 \\
\hline $\begin{array}{l}\text { Sending financial services through the phone to the customer has increased the } \\
\text { customer trust on the bank. }\end{array}$ & 1.092 & 4.08 \\
\hline $\begin{array}{l}\text { Sending financial services through the phone to the customer has increased the } \\
\text { customer satisfaction. }\end{array}$ & 1.040 & 4.04 \\
\hline
\end{tabular}

\section{Conclusion}

This study concluded that there are statistical significant differences between the electronic banking services which have been offered by Sudanese banks and customer satisfaction. Besides that, there are statistical significant differences between customer expectation to the dimensions of quality of electronic banking services 
and actual performance to electronic banking services. Furthermore, the customers become more satisfied with the quality of electronic banking service such as; web-services, automatic teller machines and phone banking services. The result of the study showed that all hypothesis of the study are accepted. Further studies, could be expanded to other banks in Sudan, and other factors could be addressed such as ease of use, information reliability, speed of transactions and security of the transactions in the Sudanese banking sector.

\section{References}

Alabed, S. A. (2003). Electronic Banking, available at http://www.bankersonline.com/technology/gurus_tech081803d.html

Alawamleh, M., \& Ismail, L. (2017). The impact of online banking of customer satisfaction in Jodradn. Journal of organizational studies and innovation, 4(2).

Alhaliq, H. A., \& AlMuhirat, A. A. (2016). Customer satisfaction with electronic banking services in the Saudi banking sector. Asian Social Science, 12(5), 139-146. https://doi.org/10.5539/ass.v12n5p139

Alhori, F. (2006). Information technology strategies and its role in enhancing competitive strategies, a case study on Jordanian banking sector. Abasaer Journal, 2.

Ariff, M., Yun, L., Zakuan, N., \& Jusoh, A. (2012). Examining dimensions of electronic service quality for internet banking services. International Congress on Interdisciplinary Business and Social Science. Procedia- Social and behavioral Science, 65, 854-859. https://doi.org/10.1016/j.sbspro.2012.11.210

Asad, M., Mohajerani, N., \& Nourseresh, M. (2016). Prioritizing factors affecting customer satisfaction in the internet banking system based on cause and effect relationships. 1st International Conference on Applied Economics and Business. Procedia- Economic and Finance, 36, 210-219. https://doi.org/10.1016/S2212-5671(16)30032-6

Daniel, E. (1999). Provision of electronic banking in the UK and the republic of Ireland. International Journal of Bank Marketing, 17, 72-83. https://doi.org/10.1108/02652329910258934

Eid, M. I. (2011). Determinants of e-commerce customer satisfaction, trust, and loyalty in Saudi Arabia. Journal of Electronic Commerce Research, 12(1), 78-93.

Ling, G., Fern, Y., Boon, L., \& Huat, T. (2016). Understanding customer satisfaction of internet banking: A case study in Malacca. Fifth International Conference on Marketing and Retailing. Procedia- Economics and Finance, 37, 80-85. https://doi.org/10.1016/S2212-5671(16)30096-X

Mohammed, S. K., \& Siba S. M. (2009). Service quality evaluation in internet banking: an empirical study in India. International Journal of Indian Culture and Business Management, 2(1), 12-19.

Munusamy, J., Chelliah, S., \& Mun, H. (2010). Service quality delivery and its impact on customer satisfaction in the banking sector in Malaysia. International journal of Innovation, Management and Technology, 4, 398-404.

Navaratnaseelan, J., \& Elangkumaran, P. (2014). Impact of service quality on customer satisfaction: A study on customers of commercial bank of Ceylon PLC Trincomalee District. Proceeding of the 3rd International Conference on Management and Economics, Srilanka. 359-364.

Parasuraman, A. et al. (2005). E-S-QUAL, A multiple-item scale for assessing electronic service quality. Journal of Service Research, 7(3), 213-233. https://doi.org/10.1177/1094670504271156

\section{Copyrights}

Copyright for this article is retained by the author(s), with first publication rights granted to the journal.

This is an open-access article distributed under the terms and conditions of the Creative Commons Attribution license (http://creativecommons.org/licenses/by/4.0/). 